\title{
The Use of Hybrid-selected Template Increases the Specificity of the Polymerase Chain Reaction
}

\author{
William T. Lucas and Julius S. Youngner \\ Department of Molecular Genetics and Biochemistry, University of Pittsburgh, School of Medicine, \\ Pittsburgh, Pennsylvania 15261
}

\begin{abstract}
An efficient method for generating full-length DNA sequences from apparently unsuccessful polymerase chain reactions (PCR) has been developed. In cases where nonspecific background interferes with detection of the PCR product, a second amplification is performed using a nested set of primers. The internal fragment of DNA amplified in this reaction is then blotted to a membrane and used to hybrid-select the desired DNA from the initial amplification. This DNA is eluted and used as the template for a third round of PCR. The re-use of the original primers from the initial reaction enables the final PCR to generate full-length DNA. This technique was used to clone a full-length gene segment 8 from a mutant influenza A/WSN/33 (H1N1) virus after initial PCR attempts had failed.
\end{abstract}

E DNA sequences has been greatly facilitated by the development of the polymerase chain reaction (PCR). ${ }^{(1)}$ Unfortunately, the PCR can be complicated by a number of variables that may cause less than desired results. Problems with the specificity of the reaction often occur when the ratio of the desired sequence to other DNA is very low. In this case, a preferential build-up of nonspecific DNA may account for a major portion of the product because generation of specific sequences begins from only a few molecules. This situation permits any undesired DNA that is produced from a mispriming event early in the reaction to be amplified to a concentration equal to or greater than the desired product. ${ }^{(2)}$

Primer design can also contribute to unacceptably high background in PCR. Short primers necessarily require a lower primer-template annealing temperature, which more readily permits mispriming to take place. These primers also have less inherent selectivity because they contain fewer nucleotides that can hybridize to the template DNA. The use of degenerate primers constructed from reverse translation of amino acid sequences frequently produces a high background. In this instance, the problem stems from the redundancy of the genetic code, which uses 61 nucleotide triplets to encode only 20 amino acids. While the degeneracy of primers constructed in this fashion can be reduced through careful selection of amino acid sequence and codon utilization probabilities for a given species, ${ }^{(3)}$ attempts at PCR with this type of primer are often unsuccessful. Other factors, such as excess primers or excess polymerase, have also been suggested as possible causes of failure with PCR.

To circumvent the problem of specificity of amplification with PCR, several methods have been developed. Altered reaction parameters such as reduced polymerization cycle time, increased primer annealing temperature, and decreased concentration of $\mathrm{MgCl}_{2}$ have all been used to reduce nonspecific amplification. Recently, an improved method of PCR that adds the nucleotide mix to an already denatured reaction, which is held at $80^{\circ} \mathrm{C}$, has been reported. ${ }^{(2)}$ Detection of specific amplification has also been achieved by the use of nested primer PCR. ${ }^{(4)}$ This technique makes use of a second round of PCR using the product of the initial reaction to provide the template for a second set of primers that are located internally to the primers used in the first reaction. The major drawback for this method is that the final product is shorter than the full-size DNA produced with the external primers. In this report, a method is described that uses the product of nested primer PCR to hybrid-select the full-length product of the initial reaction for amplification with the external primers. This hybrid-selection method has an advantage over nested primer PCR, namely, it produces the full-size DNA fragment rather than a reduced-size product. Additional variations of this technique that do not require nested primer PCR are also discussed.

\section{MATERIALS AND METHODS}

A mutant virus of $\mathrm{A} / \mathrm{WSN} / 33$ (H1N1), WSN-PI, was isolated from a long-term 
persistent infection initiated in this laboratory. ${ }^{(5)}$ Influenza viruses A/Washington/897/80 (H3N2) and the $6+2$ reassortant A/Washington/897/80 (H3N2) CR-48 were obtained from Dr. Brian Murphy (NIH). The plasmid pAPR801 containing the cloned segment 8 of influenza A/PR/8/34 (H1N1) was kindly provided by Dr. Peter Palese (Mt. Sinai School of Medicine). External primers for segment 8 (NS gene) were NS1-AGCAAAAGCAGGGTGAC, which hybridizes to nucleotides $874-890$ of the virion RNA, and NS4-AGTAGAAACAAGGGTGT, which corresponds to nucleotides 117. ${ }^{(6)}$ External primers for segment 7 (M gene) were M1-GAGCTCAGCAAAAGCAGGTAG, which hybridizes to nucleotides 1013-1027 and M2-GAGCTCAGTAGAAACAAGGTA, corresponding to nucleotides $1-15$ of virion RNA. ${ }^{(7)}$ The nested set of primers for segment 8 consisted of NS2-CCCTAAGAGGAAGA, which hybridizes to nucleotides 151164, and NS3-CTCATTACTGCTTC, which corresponds to the region $604-616 .{ }^{(6)}$ All primers were made by the Pittsburgh DNA Synthesis Facility.

RNA isolation from virions or persistently infected cells was performed using hot phenol extraction, as described. ${ }^{(8)}$ cDNA synthesis was carried out using the RiboClone cDNA synthesis system (Promega, Madison, WI) with $20 \mathrm{nM}$ of M1 or NS1 primer added. PCR was performed with the GeneAmp system (Perkin-Elmer Cetus, Norwalk, CT) under the following conditions: annealing, $2 \mathrm{~min}$ at $45^{\circ} \mathrm{C}$; extension, $1 \mathrm{~min}$ at $72^{\circ} \mathrm{C}$; denaturation, $1 \mathrm{~min}$ at $94^{\circ} \mathrm{C} ; 30$ cycles.

PCR products were analyzed by electrophoresis on 1\% agarose-TAE (40 mM Tris-acetate, $1 \mathrm{~mm}$ EDTA) gels. ${ }^{(9)}$ DNA was visualized by staining the gels with ethidium bromide $(1 \mathrm{mg} / \mathrm{ml})$ and exposing the gels to UV light. DNA was excised from the gel band with the USBioclean glass powder DNA elution kit (United States Biochemical Corporation, Cleveland, $\mathrm{OH}$ ).

Blotting and hybrid-selection were accomplished as follows. The gel-purified 400-bp band produced by PCR using the nested set of primers for segment 8 was denatured in $0.2 \mathrm{~m} \mathrm{NaOH}$ for $10 \mathrm{~min}$. Four volumes of $10 \times$ SSC $(1 \times$ SSC is $0.15 \mathrm{M} \mathrm{NaCl}, 0.015 \mathrm{M}$ sodium citrate) were added and the solution was placed on ice. This solution was then spotted onto an approximately $0.25-\mathrm{cm}^{2}$ piece of GeneScreen membrane (DuPont-NEN,
Boston, MA) which had been presoaked in $2 \times$ SSC for $15 \mathrm{~min}$. After allowing the filter to air dry, the DNA was cross-linked to the membrane with UV light. Prehybridization and hybridization were carried out in a microtube using a modification of the Church and Gilbert procedure. ${ }^{(10)}$ Final concentrations were $50 \%$ deionized formamide, $0.25 \mathrm{M}$ $\mathrm{NaHPO}_{4}$ (pH 7.2), $0.25 \mathrm{M} \mathrm{NaCl}, 1 \mathrm{~mm}$ EDTA, $100 \mu \mathrm{g} / \mathrm{ml}$ denatured salmon sperm DNA, and 7\% SDS. Prehybridization and hybridization were carried out at $43^{\circ} \mathrm{C}$ for $1 \mathrm{hr}$ and $16 \mathrm{hr}$, respectively. Two washes of $15 \mathrm{~min}$ at $50^{\circ} \mathrm{C}$ were performed with $1 \mathrm{ml}$ each of the following three solutions: (1) $2 \times$ SSC, $0.1 \%$ SDS; (2) $25 \mathrm{~mm} \mathrm{NaHPO}_{4}$ (pH 7.2), 1 mм EDTA, $0.1 \%$ SDS; (3) $25 \mathrm{~mm} \mathrm{NaHPO}_{4}$ (pH 7.2), 1 mм EDTA, 1\% SDS. DNA was eluted from the filter by boiling in TE ( $1 \mathrm{~mm}$ Tris, $\mathrm{pH}$ 8.0, $1 \mathrm{~mm}$ EDTA) for $2 \mathrm{~min}$.

\section{RESULTS}

\section{Initial Amplification}

Studies were undertaken to clone RNA segment 8 from a mutant of influenza A/WSN/33 (H1N1) virus, WSN-PI. This gene segment had undergone an internal deletion as described in a previous report. ${ }^{(11)}$ Because the WSN-PI virus is defective for replication, only a very small amount of viral RNA is produced during infection. Cloning through the use of PCR was used to overcome this obstacle. Total RNA isolated from virusinfected cells was used along with primer NS1 to synthesize the first strand of cDNA. This primer, which hybridizes to the extreme $3^{\prime}$ end of segment 8 , should allow synthesis of a full-length cDNA copy of the gene. After first-strand synthesis, PCR was carried out with primers NS1 and NS4, which should amplify the entire NS segment. It was expected that the final product of this reaction would be a dsDNA of approximately 800-bp. PCR was also performed with cDNA generated from segment 7 of viruses $\mathrm{A} /$ Washington/897/80 and A/Washington/897/80 CR-48 using primers M1 and M2. These reactions were used to control for cDNA synthesis and PCR amplification; in addition, the use of different viruses and primers avoided possible contamination of the segment 8 reaction. When the reaction products were examined on a gel, only a nonspecific smear could be detected in the am- plification of segment 8 with primers NS1 and NS4 (Fig. 1, lane 3), while distinct bands were present in the control reactions (Fig. 1, lanes 1 and 2). Reamplification of the original segment 8 reaction with the same primers was again plagued by background problems and produced only a suggestion of the expected band at about 800-bp (Fig. 2, lane 1). Attempts at amplification of DNA isolated from lane 3 of the gel shown in Figure 1 yielded equally unacceptable results.

\section{Nested Primer PCR}

Since the initial rounds of PCR using the external primers NS1 and NS4 did not provide a single species of DNA, it was decided that amplification with a nested set of primers could be used to insure that segment 8 DNA was present. It had been shown previously that amplification with an internal or nested set of primers greatly increases the level of product detected by PCR. ${ }^{(4)}$ When a nested set of primers (NS2 and NS3) was used to amplify the original WSN-PI reaction, a strong band at approximately 400-bp was seen (Fig. 2, lane 2). This band was smaller than the one generated when full-length segment 8 cDNA from the plasmid pAPR801 was amplified with the internal primers (Fig. 2, lane 4). This

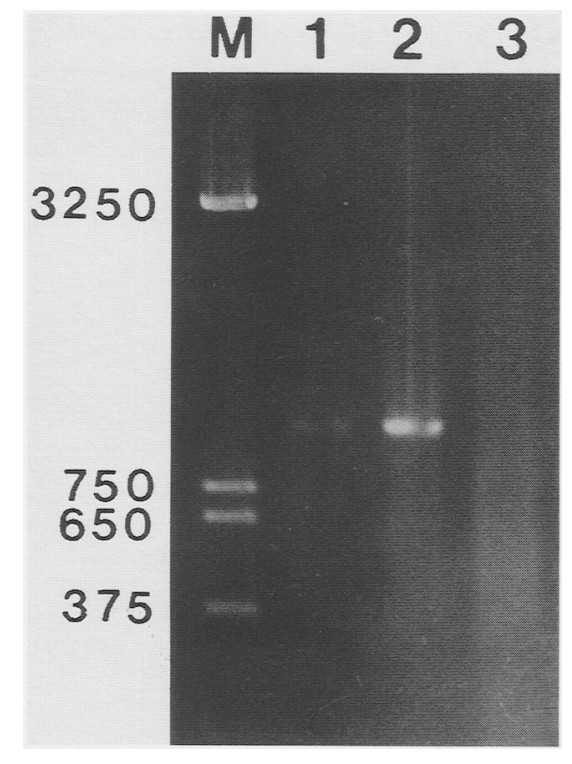

FIGURE 1 Original PCR amplification of influenza segments 7 and 8 using external primers. ( $M$ ) Markers; (lane 1) segment 7 of A/Washington/897/80; (lane 2) segment 7 of A/Washington/897/80 CR-48; (lane 3) segment 8 of WSN-PI mutant. 

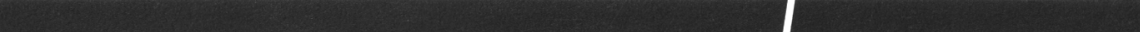

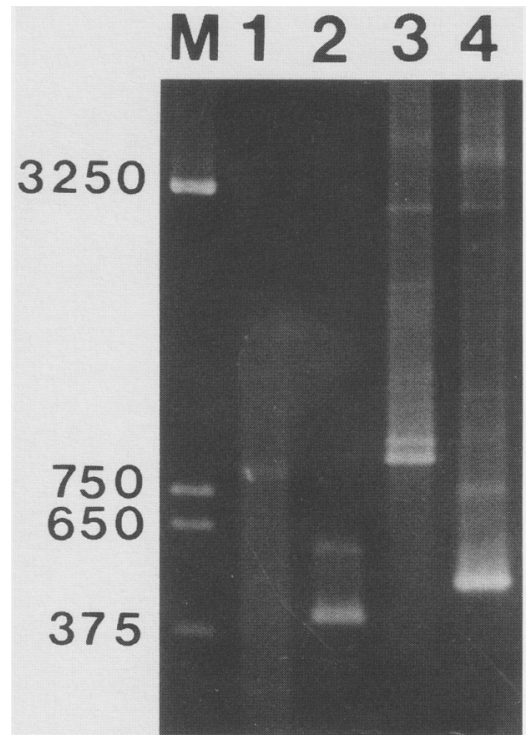

FIGURE 2 PCR amplification of segment 8 using both internal and external primers. $(M)$ Markers; (lane 1) reamplification of initial PCR of segment 8 from WSN-PI with external primers; (lane 2) reamplification of PCR of WSN-PI using internal primers; (lane 3) PCR of pAPR801 using external primers; (lane 4) PCR of pAPR801 using internal primers.

evidence of an internal deletion confirmed that the cDNA of viral RNA segment 8 from the mutant WSN-PI was present in the initial amplification and that the product was not due to contamination.

\section{Hybrid-Selected PCR}

Since the goal of these experiments was to clone and sequence the mutant segment 8 from WSN-PI, it was necessary to purify this DNA away from the background found in the initial PCR. Because the nested primer amplification yielded a single product consisting of an internal region of the desired cDNA, an attempt was made to purify a full-length copy of the mutant segment 8 from the initial amplification by hybridization to the DNA generated in the nested primer reaction. The 400-bp band seen in Figure 2 (lane 2) was cut from the gel and purified by glass powder binding. This purification was used to remove the remaining internal primers so that they would not interfere with the selection process. This DNA was then denatured with $\mathrm{NaOH}$, spotted onto a nylon membrane, and cross-linked to the membrane with UV light. An aliquot of the initial PCR that had used the external primers was then hybridized to this blot overnight. Following stringent washings, the hybrid-selected product of the initial reaction was eluted from the membrane by boiling and was used as template for PCR with the external primers NS1 and NS2. The DNA amplified by this hybrid-selected reaction appeared as a single band of approximately 800-bp when run on an agarose gel (Fig. 3, lane 2). When the mutant segment 8 was amplified with the external primers, the DNA product was smaller than the product generated by a reaction using external primers and a full-length segment 8 cDNA template (Fig. 3, lane 1). Again the presence of this internal deletion in the hybrid-selected amplification product suggested that the mutant segment 8 cDNA had been amplified correctly and that the band produced was not due to inadvertent contamination with a clone of the wild-type segment 8 . The identity of the $800-b p$ product as a mutant form of segment 8 was confirmed by subsequent cloning and sequencing procedures (data not shown).

\section{DISCUSSION}

The hybrid-selected PCR method presented in this report (Fig. 4) was designed to circumvent a problem com-

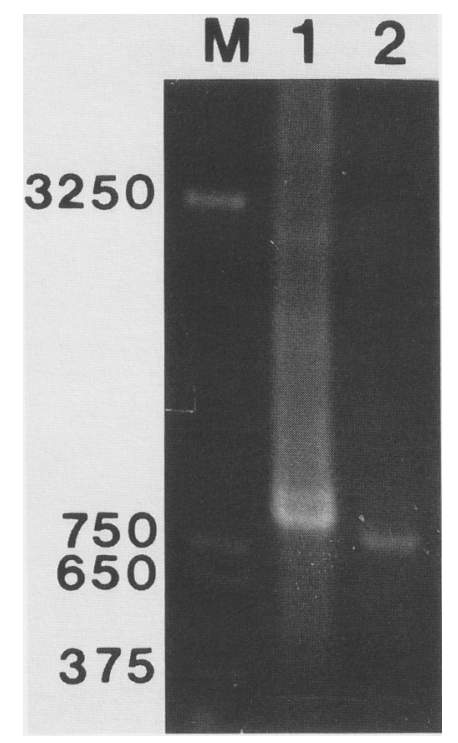

FIGURE 3 PCR using hybrid-selected template.( $M$ ) Markers; (lane 1 ) PCR of pAPR801 using external primers; (lane 2) PCR of DNA hybrid-selected from the initial segment 8 reaction using external primers. monly encountered with PCR, namely, nonspecific amplification of irrelevant DNA. In cases where an initial amplification fails to produce a specific DNA sequence, hybrid-selected PCR can be used to isolate and then amplify the desired sequence. This procedure can be readily performed because it introduces no new or uncommon techniques or reagents. Additionally, hybrid-selected PCR has a major advantage over methods such as nested primer PCR: a full-length product is produced.

In cases where reverse translation of amino acid sequences is used to produce primers for PCR, degenerate primers are the rule. These degenerate primers often cause amplifications to fail due to high background. Hybrid-selected PCR should be especially useful in these situations. The use of an internal set of degenerate primers in the second amplification gives a much greater probability of amplifying a specific sequence, which can then be used for selection. In cases where very little amino acid sequence is known, the second amplification can be carried out with one internal primer and one of the external primers used in the initial reaction. While this three-primer method would not be as selective as the four-primer method, it may be sufficient in some instances.

The use of a nested primer amplification step is not an essential part of hybrid-selected PCR. Any nucleic acid that will hybridize specifically to the sequence of interest could in theory be used. However, it is essential that if the selecting nucleic acid is DNA it should not contain sequences that will hybridize to the primers used in any further reactions. This precaution will prevent the introduction of contamination from the selecting process. Because any hybridizable nucleic acid can serve as a selector, this method may be applicable to cloning gene families or related genes from different species. And because these sequences are often cross-hybridizing, once one is isolated it can be used to select other related sequences. By using low annealing temperatures in the first several cycles of the initial reaction, the same primer sequences may be "forced" into a related DNA that in actuality has mismatches in the primer region. The removal of nonspecific background by hybridization to a related sequence should then create the ideal template for an additional amplification under stringent 


\section{HYBRID-SELECTED P.CR}

CDNA SYNTHESIS

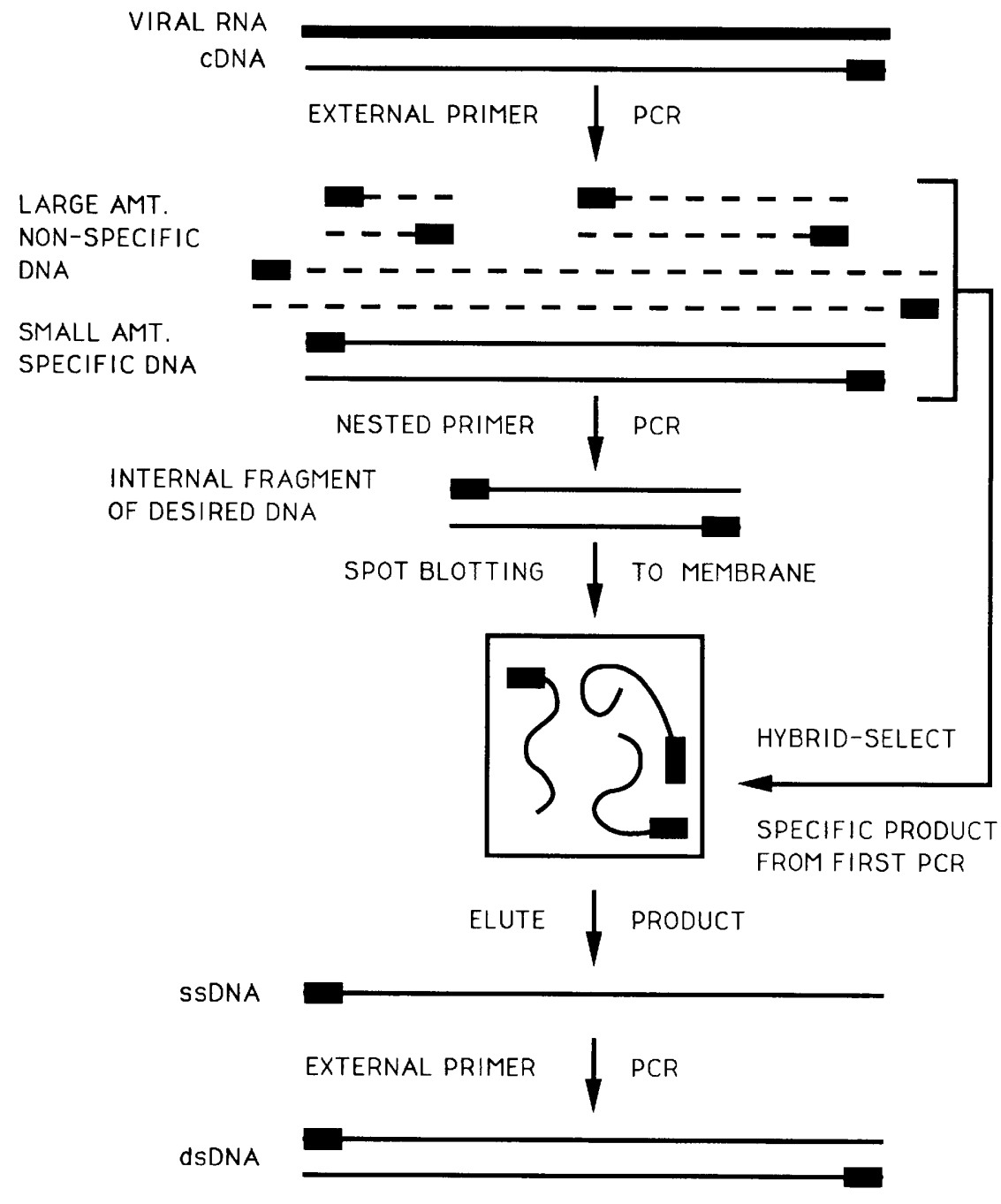

FINAL PRODUCT IS FULL LENGTH

FICURE 4 Schematic of the method of hybrid-selected polymerase chain reaction using the product of a nested primer PCR for the selection process.

annealing conditions. The use of this method should greatly ease the cloning process in these situations and increase the range of PCR applications.

\section{ACKNOWLEDGMENTS}

The authors thank Dr. Brian Murphy for supplying influenza viruses and Dr. Peter Palese for providing the plasmid pAPR801. This work was supported by Public Health Service Research Grant AI06264 from the National Institute of Allergy and Infectious Diseases.

\section{REFERENCES}

1. Saiki, R.K., D.H. Gelfand, S. Stoffel, S.J. Scharf, R. Higuchi, G.T. Horn, K.B. Mullis, and H.A. Erlich. 1988. Primer-directed enzymatic amplification of DNA with a thermostable DNA polymerase. Science 239: 487-491.

2. Mullis, K.B. 1991. The polymerase chain reaction in an anemic mode: How to avoid cold oligodeoxyribonuclear fusion. PCR Methods Applic.1: 1-4.

3. Lathe, R. 1985. Synthetic oligonucleotide probes deduced from amino acid sequence data: Theoretical and practical considerations. J. Mol. Biol.183: 1-12.

4. Mullis, K.B. and F.A. Faloona. 1987. Spe- cific synthesis of DNA in vitro via a polymerase-catalyzed chain reaction. Methods Enzymol. 155: 335-350.

5. Frielle, D.W., D.D Huang, and J.S. Youngner. 1984. Persistent infection with influenza A virus: Evolution of virus mutants. Virology 138: 103-117.

6. Buonagurio, D.A., S. Nakada, J.D. Parvin, M. Krystal, P. Palese, and W.M. Fitch. 1986. Evolution of human influenza A viruses over 50 years: Rapid, uniform rate of change in NS gene. Science 232: 980-982.

7. Cox, N.J., F. Kitame, A.P. Kendal, H.F. Maassab, and C. Naeve. 1988. Identification of sequence changes in the coldadapted, live attenuated influenza vaccine strain, A/Ann Arbor/6/60 (H2N2). Virology 167: 554-567.

8. Brawerman, G. 1973. The isolation of RNA from mammalian cells. Methods Cell Biol. 7: 1-22.

9. Maniatis, T., E.F. Fritsch, and J. Sambrook. 1982. Molecular cloning: A laboratory manual. Cold Spring Harbor Laboratory Press, Cold Spring Harbor, NY.

10. Church, G.M., and W. Gilbert. 1984. Genomic sequencing. Proc. Natl. Acad. Sci. 81: 1991-1995.

11. Lucas, W.T., P. Whitaker-Dowling, C.R. Kaifer, and J.S. Youngner. 1988. Characterization of a unique protein produced by influenza $A$ virus recovered from a long-term persistent infection. Virology 166: 620-623.

Received March 13, 1992; accepted in revised form April 7, 1992. 


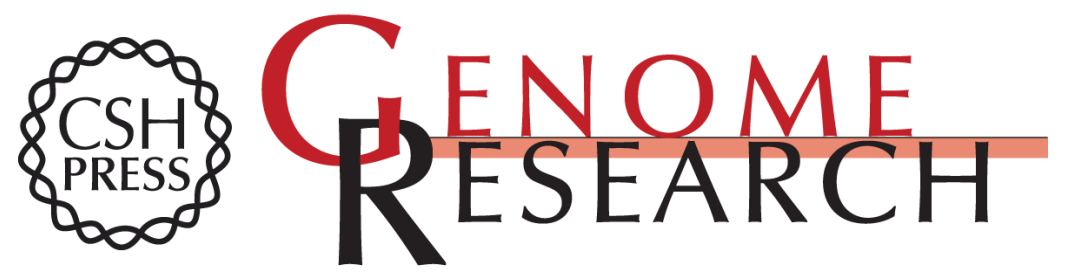

\section{The use of hybrid-selected template increases the specificity of the polymerase chain reaction.}

W T Lucas and J S Youngner

Genome Res. 1992 2: 41-44

Access the most recent version at doi:10.1101/gr.2.1.41

References This article cites 10 articles, 3 of which can be accessed free at:

http://genome.cshlp.org/content/2/1/41.full.html\#ref-list-1

\section{License}

Email Alerting Receive free email alerts when new articles cite this article - sign up in the box at the Service top right corner of the article or click here.

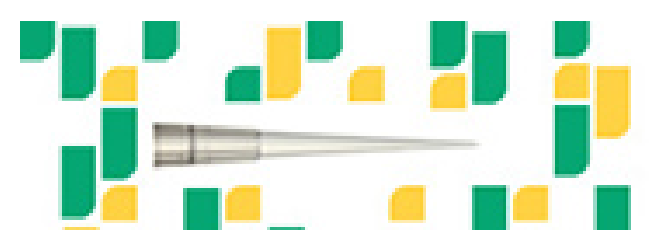

To subscribe to Genome Research go to: https://genome.cshlp.org/subscriptions 